\title{
Consequences of Koshi flood 2008 in terms of sedimentation characteristics and agricultural practices
}

\author{
K. R. Kafle ${ }^{1}$, S. N. Khanal ${ }^{1}$ and R. K. Dahal ${ }^{2^{*}}$
}

\begin{abstract}
Background: Koshi flood of August 2008 in eastern lowlands of Nepal affected around 2.64 million people in India and Nepal, including 65,000 people and 700 ha fertile land in Nepal. It was calculated that 25\% of the affected cultivated land of Shreepur, Haripur and western Kushaha villages in Sunsari district are still barren and remain filled with flood sediment of sizes from clay to sand even after 8 years. The issues of land change from fertile to barren because of flooding and characteristics of the sediments in terms of cultivation are the foci of this research.

Results: Field measurement and information from questionnaire survey showed that the depth of the flood sediment are highly variable in impacted zones. They are divided into central red, red, yellow and green zones as per the thickness of the sediments. The sediments from sieve analysis has also shown that the degree of fineness is greater towards the green zones and texture has shown function of distance : $T=f(d)$. The average thickness varies from $0.10 \mathrm{~m}$ in green zone to $4.5 \mathrm{~m}$ in central red zone in new channel area of the flood. The crop yield is also $50-75 \%$ greater in green zones than in the other zones. Changing in cultivation practice from traditional crops to cash crops have increased income up to $200-300 \%$ in the aggraded land. Changing in cultivation practices and removing layer of flood sediment in shallow sedimentation area are the major overcomes against the flood sediments.
\end{abstract}

Conclusion: The study concluded that the agricultural practices in aggraded land depends on sediment textures, composition, and thickness of the sediments.

Keywords: Flood, Agricultural practices, Sediments

\section{Background}

The Koshi is the largest river in the eastern part of Nepal and also one of the largest tributaries of the Ganga. It's catchment starts from Tethys sediments in the north to the Nepal Siwalik range in the south. Elevating active Himalayan range with high gradient variation has made the river velocity high and high rate of denudation in high land areas. Therefore huge sedimentation by the Higher Himalayan rivers over the low land is common. On other hand, small and large rivers originating from middle mountains also contribute greatly for flooding over the low land agricultural land of the southern plain of the country.

\footnotetext{
* Correspondence: krkafle@ku.edu.np

${ }^{2}$ Geo-disaster Research Centre, Central Department of Geology, Tribhuvan

University, Kirtipur, Nepal

Full list of author information is available at the end of the article
}

The Koshi is also known as the highest silt yielding river in the world (Subramanian and Ramanathan 1996) with an estimated 118 million cum/year of sediment (Dixit 2009) which is attributed by the landslides and soil erosion in its catchment areas. Although its runoff is only about $25 \%$, it accounts for almost $50 \%$ of the country's soil erosion (Nayak 1996). This value indicates the intensity of fluvial sedimentation in the river.

Sedimentation is a matter of grave concern with respect to the Koshi rivers/tributaries which spans a staggering length of $720 \mathrm{~km}$ with about $92,538 \mathrm{~km}^{2}$ of drainage area (Nayak 1996). Huge deposition on the low land area governs the river channel system and the river has shown to be shifted $115 \mathrm{~km}$ westwards in the last 200 years (Agarwal and Bhoj 1992; Gole and Chitale 1966) covering $770 \mathrm{~km}^{2}$ with sand (Nayak 1996). The dynamism of the Koshi is described by the cause of lateral shifting, frequent flooding, "piggyback" thrusting 
sequences, extensive bank erosion, neotectonics, tilting, sedimentological adjustment in its basin (Nepal et al. 2014; Ghatak et al. 2012; Rahman 2011; Jain and Sinha 2005; Nakayama and Ulak 1999; Sinha 1998; Khalequzzaman 1994; Blair and McPherson 1994; Schelling 1992; Agarwal and Bhoj 1992). This shifting dynamics result in the destruction of floodplains and the agricultural lands (Moench 2010). After the construction of the Koshi Barrage in 1962; eight major floods have been occurred since last 55 years (Mazumder 2011). On other hand, a research indicated that the sediments supply is limited in Nepal Himalayas which shows that the precipitation is not the only cause of erosion (Andermanna et al. 2012). Climatic and tectonic variations have contributed to the geomorphic diversity across the flood plain (Sinha et al. 2005). The flood fed sedimentation poses a challenge because of infertility and hardly used except in small quantities for construction materials (Hooning 2011). The existence of dynamism of hydrological system in Gangetic rivers is therefore vulnerable and is characterized by shifting of the channel along with the flood sediments which directly affects the people in the basin (Ghatak et al. 2012).

Sedimentation is a natural process for balancing on subsiding sedimentary basin by distributing sediments over an area. The short term sedimentation covers around the local area along the channel (Richards et al. 1993) and the accumulated sediments force the river to form of braided system and the river frequently enters nearby areas, especially in low lands, in an aggressive way during the monsoon seasons in the Terai (low land) region of Nepal.

Although a number of significant studies have been carried out for several decades (Sinha et al. 2010) the data availability of the Gangetic basin is still scanty. Similarly, Hooning (2011) has also mentioned that reliable data of previous floods and sedimentation parameters of the Koshi river are not available satisfactorily. Nevertheless, studies over 50 years have shown that the low lands (known as Terai) of Koshi basin located downstream from Chatara lies in high flood disaster risk zone because of poor maintenance and monitoring in existing civil structures with poor understanding of the river dynamics.

The soil quality in agricultural land is degrading in most of the paddy fields. Tiwari et al. (2006) has classified and indicated degrading trend with Soil Quality Index of Paddy land (Khet) 0.23 out of 1.0. Soil parameters measurement and reporting would not be sufficient until and unless reorganization of the dynamics of the balancing the different components (Karlen et al. 1995) of the dynamics of living system, including physical, biological and chemical are taken into consideration. In particular, the flood induced sedimentation on the agricultural field can be taken as much significant in terms of storage and remobilization in the movement of sediment (Walling 1988). Schreier et al. (1999) has also described the balancing and interaction of soil properties in new water and sediments fed from the river in the monsoon. The traditional agricultural management method should be reformed and develop as per the situation of post disaster phase. Regmi and Zoebisch (2004) has also emphasized the need for development of the new guidelines for such management rather than continuing the existing conventional practices.

The intense problem of sedimentation of the Koshi in the low land is frequent and the sedimentation hazards are always seen particularly in the settlements adjoining the river banks. The people in these settlements are heavily dependent on agricultural resources. However, the agricultural resources and its production potentials are always in threat due to frequent high sediment floods. On the other hand, the post disaster impact assessment on the nature of flood especially on the impact of sedimentation in agricultural land has always been deemed insufficient, especially in of the low land areas of Nepal. Thus there is an urgent need to assess the impacts of the flood-induced sedimentation as a part of pre and post disaster management in a sustainable manner especially in agricultural land and post disaster productivity.

Therefore, this study attempts to assess the impacts of flood-induced sedimentation on agricultural land, physical characteristics of the sediments and cultivation practices in the affected areas during the post 2008 Koshi flood.

\section{Koshi flood}

On 18th August 2008 at 12.55 pm Koshi river diverted on its 100 years old course towards the eastern side by breaking its embankment with $90 \%$ flow of water (MoHA 2009) (Fig. 1). This flood is considered as one of the most disastrous natural events of the last decade in terms of the number of people affected and the loss of properties. The flood completely destroyed three Village Development Committees (VDC) whereas two VDCs were partially affected. The flood deposited large amounts of sand and silt on agricultural land affecting millions of people in Nepal and India including 65,000 in Nepal (MoHA 2009). The economic loss incurred by the loss the existing crops estimated at US\$18.7 million reduced the National Gross Domestic Product (GDP) by $0.3 \%$ on 2009 (ADB, Asian Development Bank 2009).

About 700 ha of fertile land was uncultivable because of the inundation of the land with flood sediments filled with sand and silt (THT, The Himalaya Times 2011) till 2011. Most of the severely affected VDCs are still in desert like conditions even after 8 years of the event. The change in the state of cultivable land to barren due to the flood sediments of Koshi is thus a major focus of this study. The 4-5 m level difference between embankment 


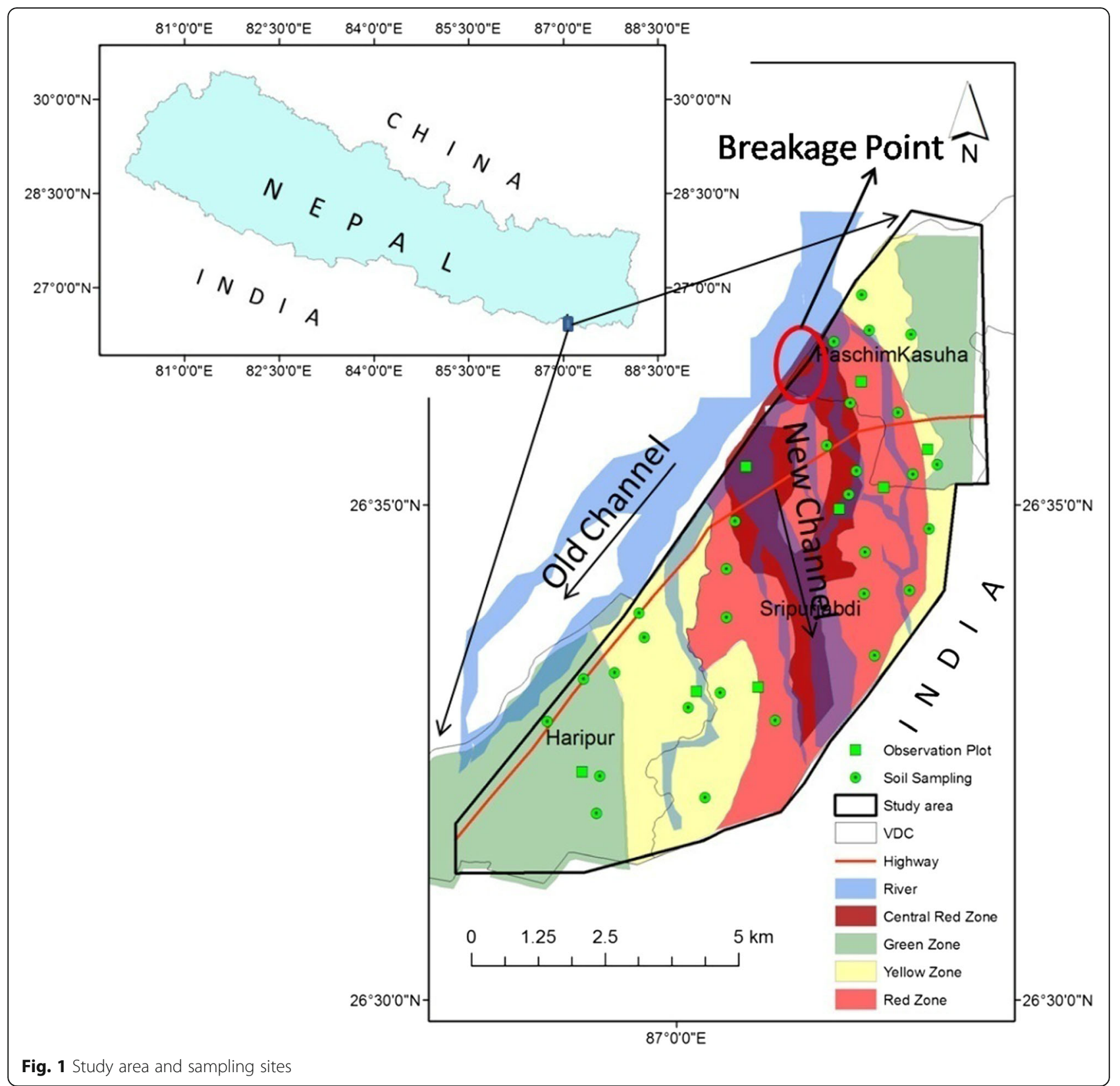

area and river channel pose further risk for recurring devastations. It has been also reported that there are several structurally critical points on the embankment that are potential for breaching in the near future as of 2008 event (Sinha and Kommula 2010).

\section{Methods}

The study comprises both primary and secondary data acquisition during period from 2008 September to 2014 December. Primary data collection includes soil sampling, auguring, observation, depth measurement of sediments, establishing observation plots, lab-scale experimental plots and questionnaire survey. Grain size and composition analysis, depth measurement, productivity and yield analysis from observation plots followed by lab plot and biomass analysis were carried out in different classified zones Central Red Zones (CRZ), Red Zone (RZ), Yellow Zone (YZ) and Green Zone (GZ).

The main aim of the questionnaire survey was to generate information on impacts and associated problems of sedimentation on the agricultural land and the communities' subsequent adaptations and adoption of agricultural practices within the flood affected areas during the post-disaster phase. Flood sedimentology and cultivation practices in the long term scenario are considered as important factors in terms of self sustaining over the heavy 
sedimentation situations. Such information is considered useful for flood-induced disaster management.

The study area (about $50 \mathrm{Sq} \mathrm{km}$ ) (Fig. 1) was divided into 7 clusters of settlements from severely affected to lightly affected areas. A semi-structured questionnaire was used with 16 questions related to sediments and agriculture practices. Five options were provided for each question relevant to post disaster issues on agriculture and flood sediments. Altogether 150 respondents were selected following Random Sampling Method (RSM). The age of the respondents were above 16 years with Standard Deviation1.249 in 90\% of the major affected villages of Nepal. Basically, the questionnaires were adopted through a study of the references of literature review for the post disaster issues. Questionnaire survey criteria have been prepared from the suggestions available in literature (such as Hussain et al. 2009; Dirkzwager et al. 2006; Önder et al. 2006; Roorda et al. 2004; Galea et al. 2003; Malilay et al. 1996; Guha-Sapir and Lechat 1986). These literatures were embedded together within a single survey questionnaire.

A total of 31 soil samples were collected with Stratified Random Sampling Method (SRSM) in different classified zones of which 29 samples were collected along the both new banks of the new channel excluding 2 samples from natural unaffected area. Out of these samples, 11 samples were collected from RZ including 5 samples into the new channel starting from the breach point which was further classified as Central Red Zone (CRZ). Similarly, 10 and 8 samples were collected from YZ and GZ respectively. Grain size analysis was conducted for the sediments with standard ASTM method. The analysis was conducted to determine the sediment size distribution and texture of the flood sediments over the agricultural land. Five gram sample was examined by binocular magnifier $(20 x)$. For this examination, mineral grains were separated by clip and pin for the counting and identification of the minerals.

Sediment samples were collected at a depth of $0.03 \mathrm{~m}$ by manual hand auger. Thickness was detected by hand augering, penetration of metal rod and digging the pits. In addition, the existing excavated trenches (Nalas), irrigation cannel were also measured for the sediments thickness. Total of 120 sites were measured for the confirmation of the thickness of the sediments and finally confirmed by concerning with villagers of the affected area.

The observation plots were surveyed through questionnaire, measurement and visual observations were also made. All together eight observation plots were selected in the classified zones i.e. CRZ, RZ, YZ and GZ. The area of each plot was 18,225 sq. ft. (5 Kaththa). The cultivation practice, yield and annual income following the years of flood were recorded in the from each of the observation plot.

\section{Laboratory plot investigation}

The laboratory investigation is conducted as per specified on Association of Official Seed Analysis (AOSA, Association of Official Seed Analysts 2002) and International Seed Testing Association (ISTA, International Seed Testing Association 2009). Both banks of the new channel's soil of the in respective zones CRZ, RZ, YZ and GZ were mixed individually. The mixed soil were placed in 10 plastic trays of dimension $16.5^{\prime \prime} \times 12.0^{\prime \prime} \times 3.0^{\prime \prime}$ for different zones separately as shown in Fig. 2 . The soil thickness was maintained at $2 \mathrm{in}$. in the tray for the experiment.

One hundred-fifty seeds of paddy and 150 seeds of wheat were chosen for the plantation in the soil in different trays as lab plot. Individual tray plot was separated again in three different zones with planting 50 each for the replication with same environment. The plants were uprooted after 1 month of plantation. Plants' wet and dry weight (zone-wise), measurement of length of plant outside and under the soil were taken.

\section{Secondary data analysis method}

The secondary data were collected from relevant organizations. The study and analysis were focused on the agriculture productivity trend after the flood event. The data were compared with the data of pre flooding phase. The comparison is useful in finding the significant variation of productivity before and after the flooding.

\section{Results and discussion}

\section{Sedimentation impact in agriculture}

The flooded land was classified in both sides/banks of the new channel. As per the site and severity, the red zone was classified into two zones: Central Red Zone (CRZ) along the new channel and Red Zone (RZ) along the water inundated area. The result from questionnaire survey showed that the disaster affected farmers' income reduced by almost $95 \%$ since $90 \%$ of the community were agriculture-dependent. The field observation also

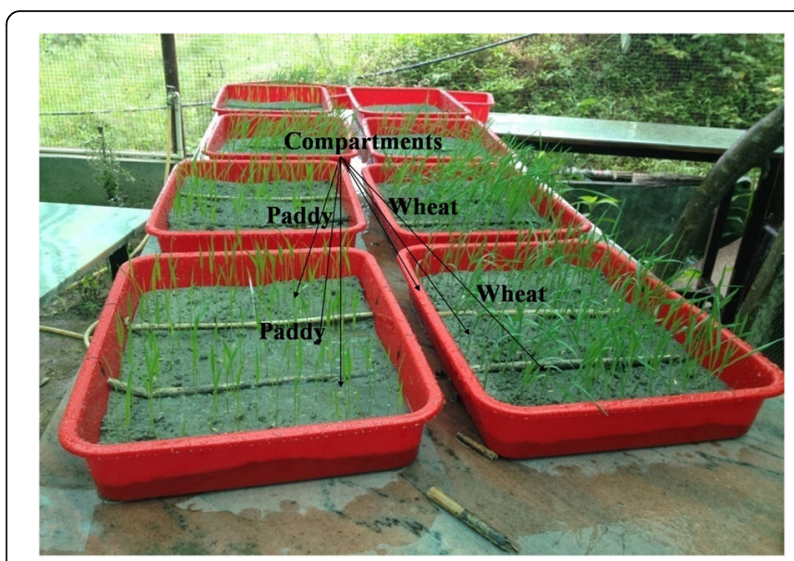

Fig. 2 Lab plots in plastic trays 
showed that the most of the fertile land, especially in Central Red (CRZ) and Red Zone (RZ), are still in form of barren land filled with sediments even after 8 years from the event. It was also observed that $20 \%$ people have changed their agricultural practices growing cash crops in order to cope with the situation.

\section{Depth of the sedimentation}

The contour (Fig. 3) shows that the thickness of sediments are concentrated towards the central and right bank of the new channel on most of the CRZ and RZ area. The thickness varies from 1 to $4.5 \mathrm{~m}$ in that area. The depth is decreasing towards the $\mathrm{YZ}$ and GZ on both sides of the new channel. However, the thickness of sedimentation is also varied within the classified zones because of the new channel morphology.

\section{Composition of grain and grain size distribution}

The mineralogical composition of sediments has little variation with zones from CRZ to RZ except quartz, mica and carbonate. Quartz seems to be lesser towards the green zones whereas mica and carbonate have shown increasing trends. Quartz is dominant in all the zones. However, the percentage is decreasing towards the distance from the main channel. In main channel CRZ, percentage of quartz varies from 60 to $70 \%$ and it is lesser in GZ and NZ. Similarly, other major constituents are feldspar and mica along with $0-20 \%$ of carbonate (Fig. 4).
Chlorite, biotite and iron oxides are the minor constituents in most of the zones.

Fine grain size is greater in GZ, YZ and unaffected NZ whereas the size is coarser on red zones (Fig. 5). Most common sizes of sand over all zones are medium fine to medium. Gravel is absent even in red zones. The red zones (CRZ \& RZ) are generally unsuitable to traditional crops (rice and wheat) from agricultural point of view as per farmers' experiences. The available grain size distribution percentage in $\mathrm{YZ}, \mathrm{GZ}$ shows the suitability for traditional crops.

The soil texture analysis is shown (Fig. 6). RZ and CRZ soil have sandy texture whereas finer soil is present in YZ and GZ. Therefore, YZ and GZ have loamy sand and sandy loam respectively. In this texture plot, it has been seen that the sand is also significantly present in NZ.

\section{Moisture, density and $\mathrm{pH}$ of natural soil and sediments}

On the base of the soil sampling as shown in Fig. 1 as soil sampling sites, $\mathrm{pH}$ value ranged from 6.5 to 6.8 in normal soil indicating its mild acidic in nature. However, the top soil or sediments' $\mathrm{pH}$ value ranged above 7-7.8 which indicates mild alkalinity (Fig. 7). The difference in the $\mathrm{pH}$ values clearly indicates the difference in $\mathrm{pH}$ in pre-flood soil and flood sediments as top soil.

Research in the low land have shown the Khet (Paddy field) to have relatively lower $\mathrm{pH}$ value possibly due to higher chemical fertilizer use (Regmi and Zoebisch 2004; Schreier et al. 1999). However, it has been reported that

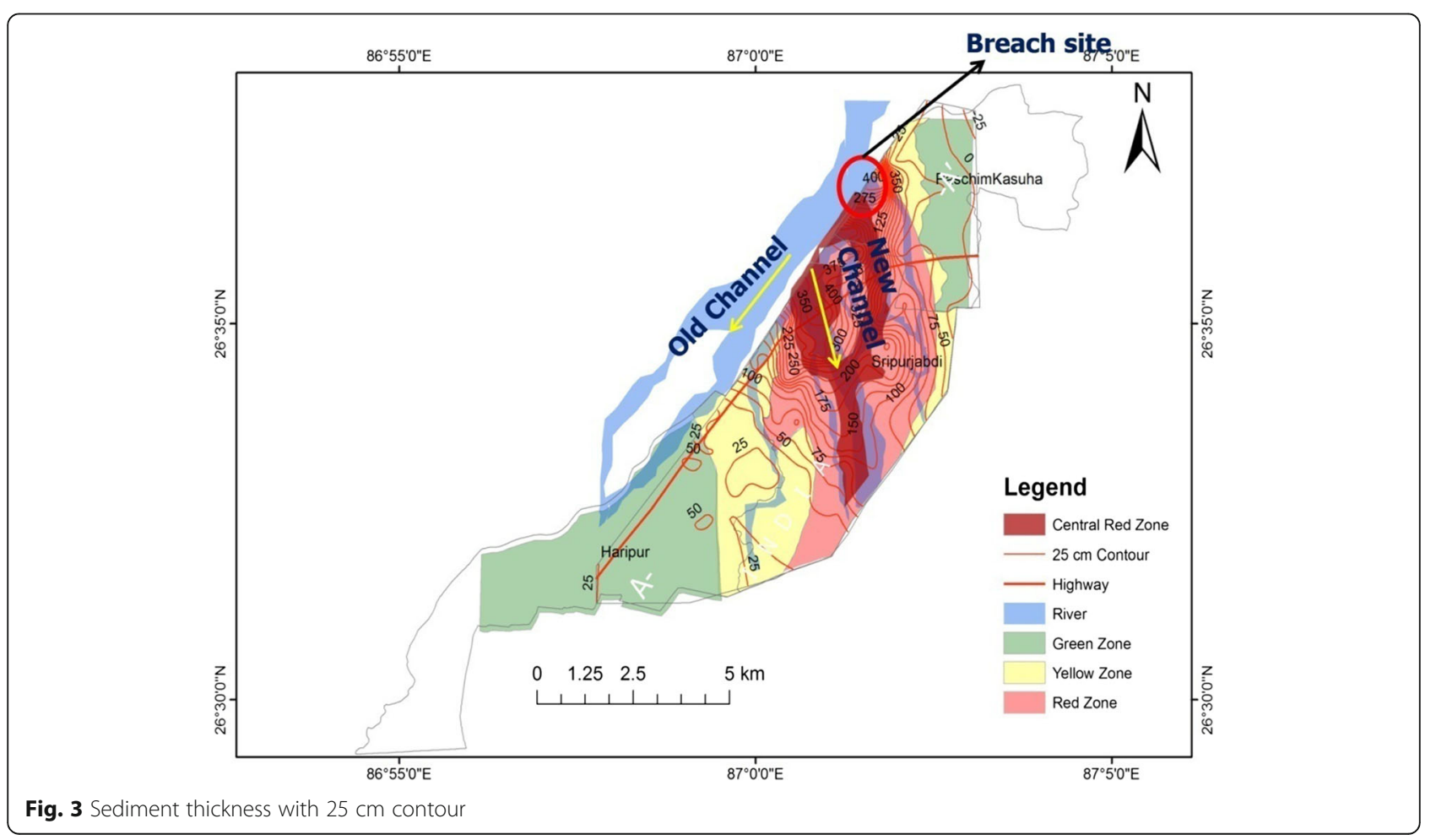




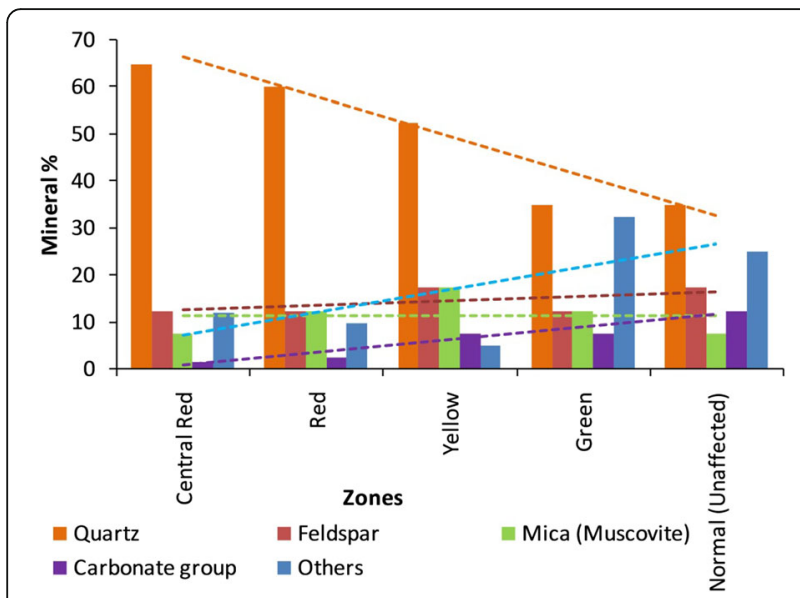

Fig. 4 Sediments composition in different zones

sediments and irrigation water can increase $\mathrm{pH}$ values up to 0.5 units in the existing lands. Apart from this, limestones and chalks from the Tamor river (Mahato and Shukla 2013) in the form of sediments contribute for the alkalinity in the soil. The alkaline nature in sediments reflects the bedrock composition of the Lesser Himalayan rocks that comprises of minerals rich $\mathrm{K}, \mathrm{Na}$, $\mathrm{Ca}, \mathrm{Mg}$, carbonate rocks.

The average Bulk Density (BD) of the sediment varies from 1.43 to $1.64 \mathrm{~g} / \mathrm{cc}$ in the flooded land (Fig. 8). The density is lesser in $\mathrm{YZ}$ and CRZ. The BD is higher towards the natural zone.

The $\mathrm{BD}$ values indicate that the compactness is higher in natural zone compared to the new sediments. The textural range from sandy soil to loam with bulk densities 1.6 to $1.4 \mathrm{~g} / \mathrm{cc}$ in the field indicates that the porosity ranges from $40 \%$ to $47 \%$ (MAIB 2015). Based on the bulk density, the physically favorable zones for agriculture are $\mathrm{YZ}, \mathrm{GZ}$ and $\mathrm{RZ}$ in comparison to CRZ.

The moisture content measurement was conducted in dry season (May-June). The result shows that the moisture content is lower $(0.1 \%)$ in $\mathrm{RZ}$ and higher $(18.28 \%)$ in GZ. The average minimum moisture content is low in RZ and CRZ compared to GZ and NZ among affected land.

\section{Agriculture practices and cultivation changes}

Field observations and survey data showed that the farmers are able to remove the sediments from their farm land if the depth of the sediment is less than $1 \mathrm{~m}$. They were found to dump the sediment by using trucks and tractors. The investment cost was found to be recovered within the next 2 years. The study found that two-time harvesting practices existed in the affected areas. The cultivation practices was found to vary in different zones in newly formed left and right banks. Green zone's farmers were observed to be attracted towards vegetables because of being cash crops and change in the soil quality with increased fine sediment (shown in Grain size analysis) by flood instead of traditional paddy, wheat and gram. Most of the left bank area has been filled with fine clay and the existing land have become suitable for different cash crop as well as vegetable cultivation. The farmers of $\mathrm{YZ}$ area are still practicing the cultivation of winter crop-wheat. However, they have changed their summer crop from paddy to vegetable because of the sandy texture of sediments. In the CRZ, the thickness of sediments is more than $1 \mathrm{~m}$, making cultivation difficult. Therefore, they haven't cultivated the land in CRZ if the thickness was higher. However, in the

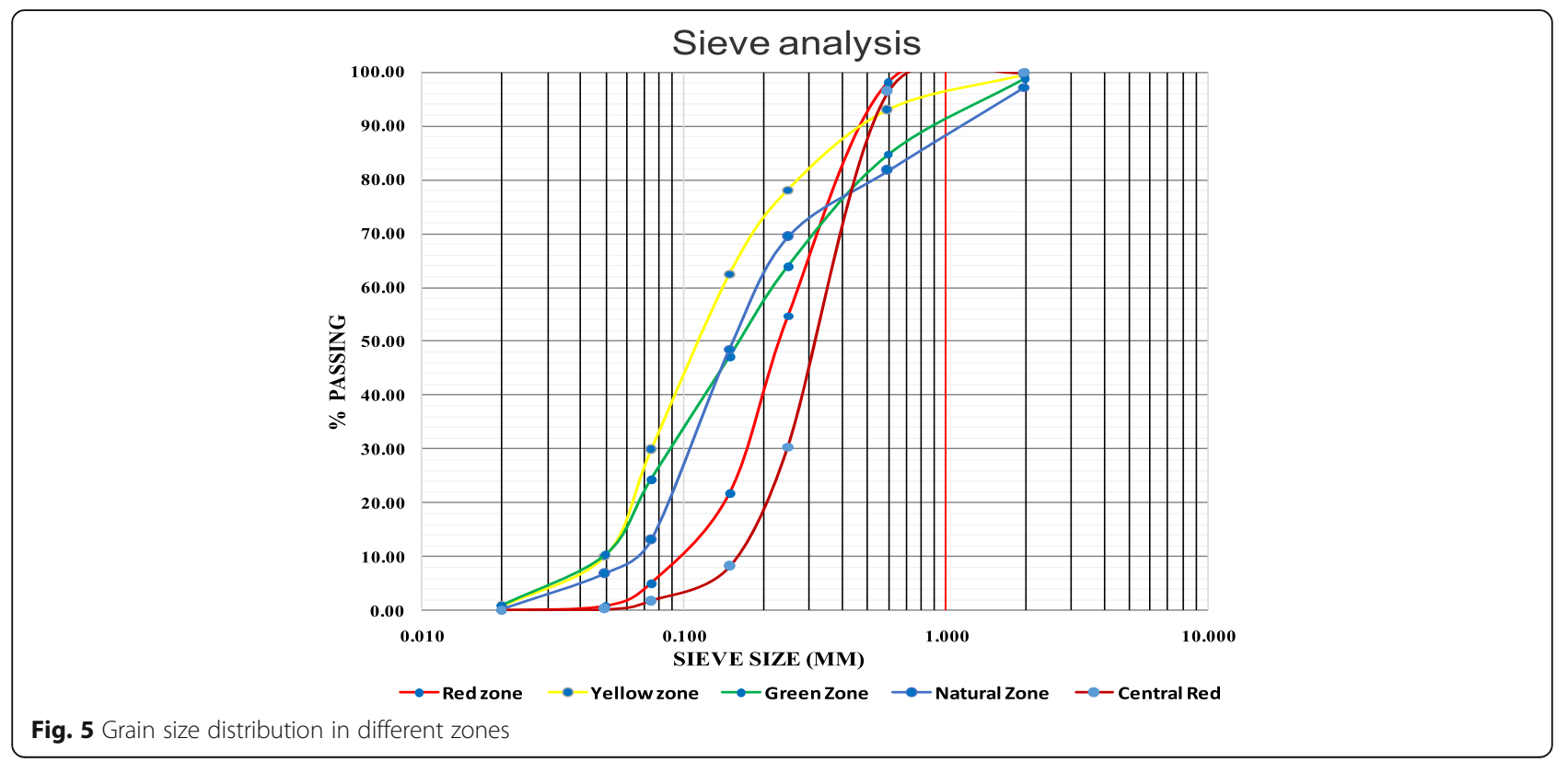




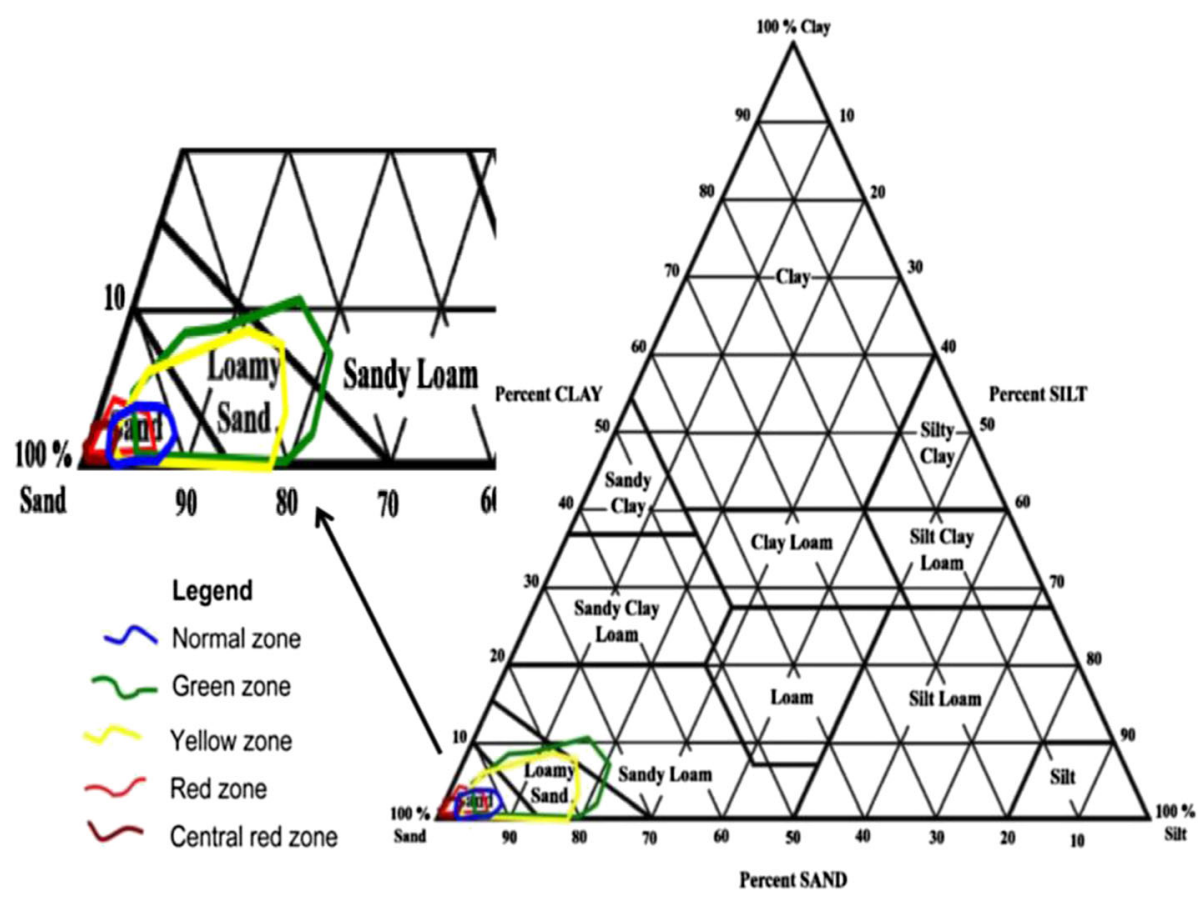

Fig. 6 Sediment textures in different zones

$\mathrm{RZ}$, the farmers were found to grow bombax (Simal), water melon, vegetables like Point Guard (Parbar) and cash crops like Sunflower and Sugarcane on the shallow $(<1 \mathrm{~m})$ sedimentation areas (Table 1$)$.

The survey shows that changing their traditional cultivation practices to new practices enable them to recover their financial loss.. The term 'field fitness' is suitable in place of 'soil fertility' (Desbiez et al. 2004) for the newly adopted cultivation practices in the new situation. The zones GZ and $\mathrm{YZ}$ in the upstream of the new channel seem to contain more nutrients from new fine sediments rendering increased productivity. The new sediments and water brought in by the flood contribute to the nutrient to the farmlands (Brown et al. 1999). Regmi and

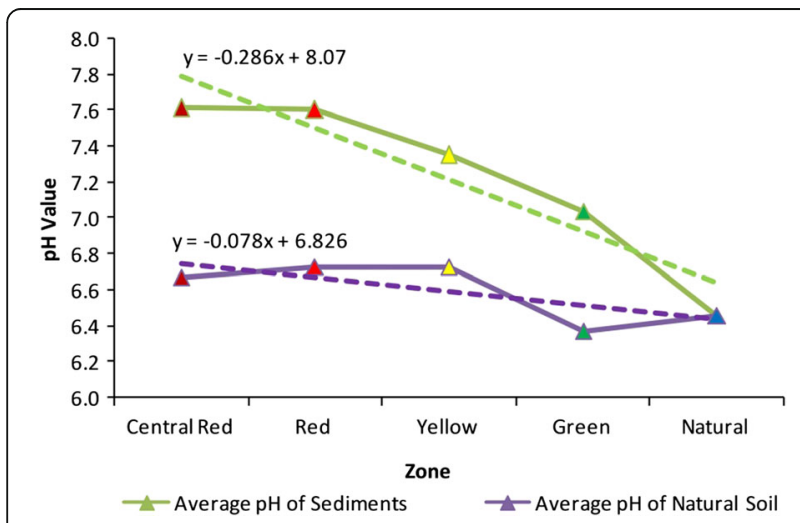

Fig. $7 \mathrm{pH}$ values in sediment Vs Natural Soil
Zoebisch (2004) has also described that the fertility of soil is directly dependent on the agriculture practices also. Therefore, only soil and nutrient change do not solely cause the productivity.

\section{Lab plot analysis and outcomes}

The average germination percentage of wheat as well as paddy was higher in NZ ( $94 \%$ and $96 \%$ respectively) whereas the germination percentage of wheat in RZ was lesser $(72 \%)$ and the germination percentage of paddy in CRZ was nil (Fig. 9).

The germination percentage indicates that sandy soil is moderately suitable to cultivation for wheat but unsuitable for rice.

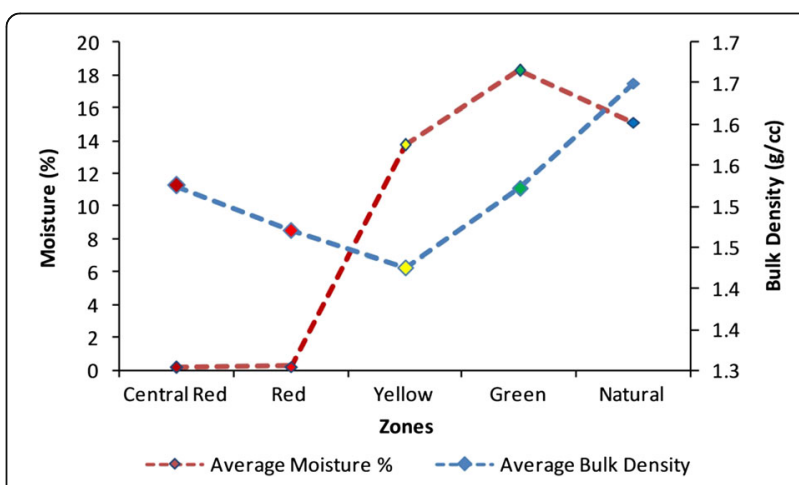

Fig. 8 Moisture and Average bulk density in different zones 
Table 1 Crop changing practices

\begin{tabular}{llll}
\hline Zone & Previous & Current & Thickness of sediments \\
\hline Cetral Red (CR) & Rice, wheat & Water melon, Parbar & $<1.5 \mathrm{~m}$ thickness of sediments \\
Cetral Red (CR) & Rice, wheat & Barren & $>2 \mathrm{~m}$ thickness if Sediments \\
Right Bank Red (RBR) & Rice, wheat & Simal, Sugarcan & $<1.0 \mathrm{~m}$ thickness if sediments \\
Left Bank Red (LBR) & Rice, wheat & Wheat & $<1.5 \mathrm{~m}$ thickness (After removing the sediments) \\
Right Bank Yelow (RBY) & Rice, wheat & Wheat & $<1.5 \mathrm{~m}$ thickness (After removing the sediments) \\
Left Bank Yellow (LBY) & Rice, wheat & Vegetables & $<0.30 \mathrm{~m}$ thickness of sediments \\
Right Bank Green (RBG) & Rice, wheat & Rice, wheat & $<0.20 \mathrm{~m}$ (No effect after a 6 months) \\
Left Bank Green (LBG) & Gram, wheat & Vegetables & $<0.20 \mathrm{~m}$ (No effect affter a 6 months) \\
\hline
\end{tabular}

The height of the plant is similar in GZ and NZ compared to $C R Z$ and $R Z$. Height varied from $0.00 \mathrm{~cm}$ (CRZ) to $22.59 \mathrm{~cm}(\mathrm{NZ})$ for paddy, whereas for wheat it ranged from $7.05 \mathrm{~cm}(\mathrm{RZ})$ to $21.81 \mathrm{~cm}$ (YZ) Although the average height is similar in $\mathrm{YZ}$ for wheat and paddy, the biggest difference was found in the case of paddy in RZ \& CRZ compared to other zones.

Comparison of plant heights in the observation and lab plots indicated that the plant with the largest height $(22.59 \mathrm{~cm})$ was paddy on NZ. The average root length $(8.85 \mathrm{~cm})$ and $(9.13 \mathrm{~cm})$ the average total length $(28$ and $29.70 \mathrm{~cm}$ ) were higher in GZ for both the paddy and wheat (Fig. 10).

Average wet weight of the wheat plant varied from $4.03 \mathrm{~g}$ in CRZ to $8.49 \mathrm{~g}$ in YZ, whereas average dry weight varied from $0.67 \mathrm{~g}$ in CRZ to $2.98 \mathrm{~g}$ in RZ (Fig. 11).

The difference in dry weight varied from $50 \%$ in CRZ to $85 \%$ in GZ. The result can be correlated to moisture content of soil-higher in GZ (18.28\%) and lower in CRZ $(0.1 \%)$. The average wet weight of the rice plant varied from $0.00 \mathrm{~g}$ in CRZ to $29.19 \mathrm{~g}$ in $\mathrm{RZ}$, whereas average dry weight varied from 0.00 in CRZ to $7.18 \mathrm{~g}$ in YZ. The difference in dry weight varied from $0.00 \%$ in $C R Z$ to $82.4 \%$ in NZ.

\section{Discussion}

Accumulation of flood sediments in the river eventually force to divert the existing channel that usually causes the breakage to the river embankment of the river and enter the adjoining settlement in a destructive way. This process is frequent in Nepal mostly in monsoon seasons especially in the lowland areas (Kafle et al. 2015).

The classified area-CRZ is completely uncultivable even after 8 years of the event. However, in RZ, farmer themselves have taken initiatives to cope with the adverse situations. Most of the area is covered with sand and silt with negligible amount of clay. Therefore, the farmers started to remove the sediments if it could be managed. They have also started to plant the trees like bombax. Similarly, cultivation of watermelon as well as sugarcane was also cultivated wherever the conditions were suitable. This change in cultivation practices started 3-5 years after the event which has also helped to recover their financial loss after the disaster. Similarly, in YZ and

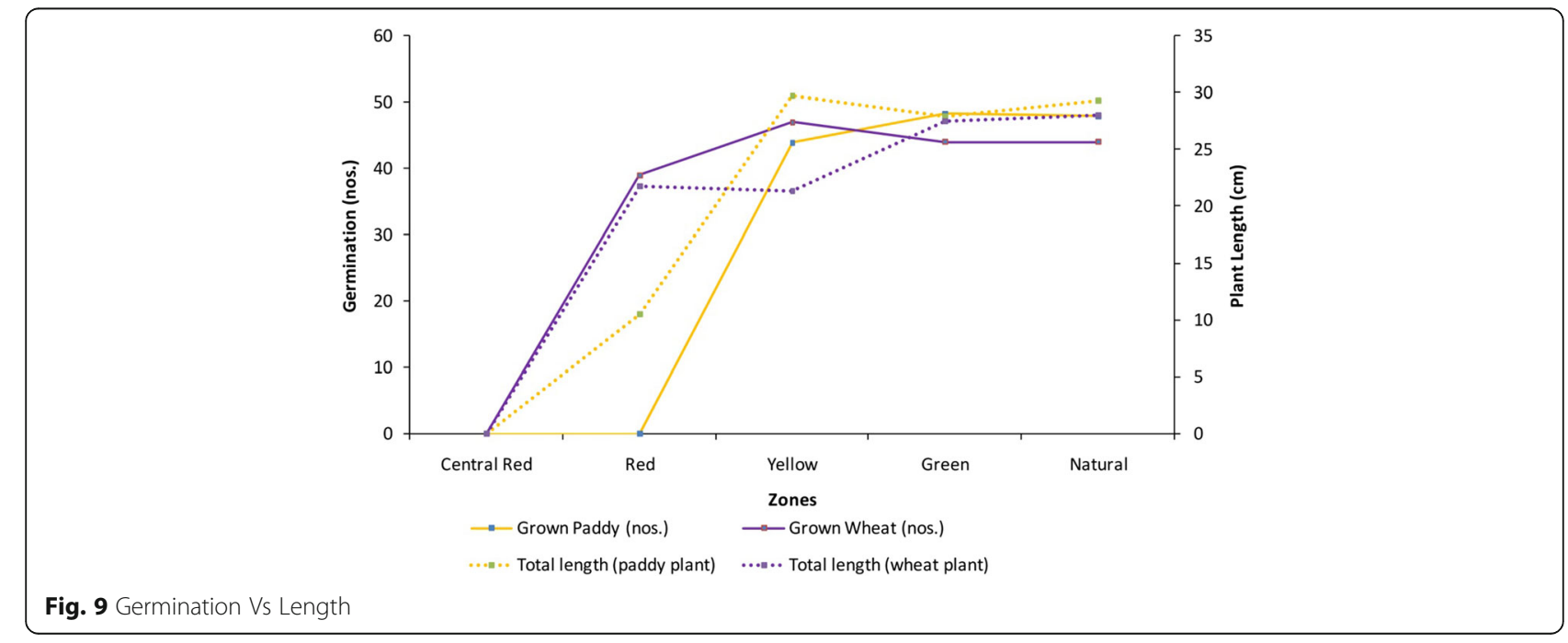




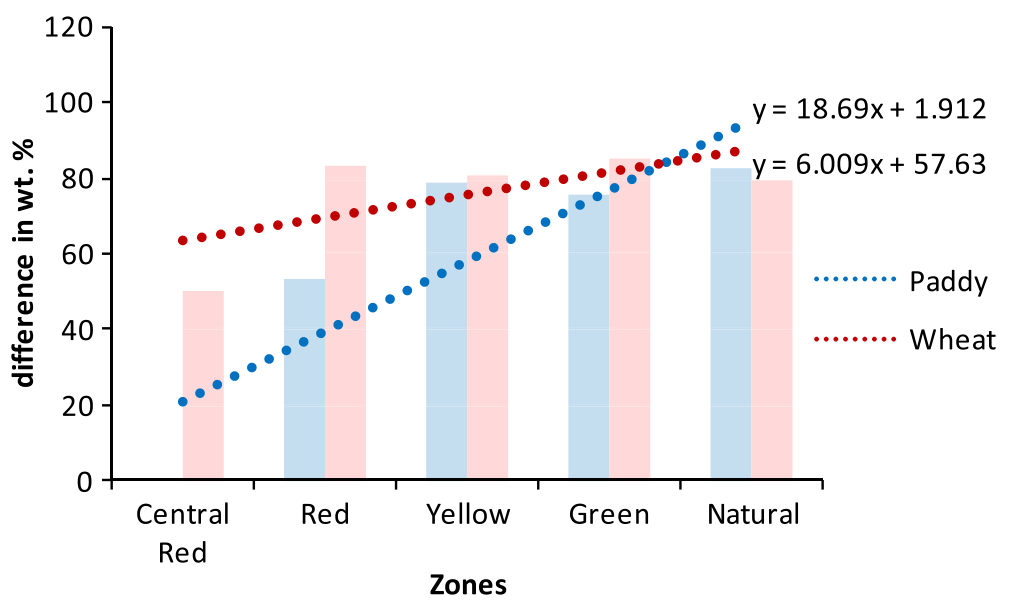

Fig. 10 Difference in weight (Wet to dry) for paddy and wheat in different zones

GZ, cultivation practices are being revived. They have changed their crops from traditional to the cash crop. However, the YZ farmers are still practicing the traditional cultivation of wheat in winter as was the norm previous to the disaster, while changing from paddy plantation to vegetable plantation in summer. The farmers of GZ are practicing vegetable cultivation instead of traditional paddy, wheat and gram.

The composition of the sediments show the dominance of quartz and feldspar. Their composition range from 12.5 to $65 \%$ respectively in average and their concentration is higher towards the RZ and CRZ, which indicates the barrenness of the land for a long time. Because these minerals do not alter or weather to form soil due to their crystalline nature specially for quartz grains. The grain size also indicated the dominating presence of sand compared to silt and clay in all of the zones. The percentage of carbonate and mica ranges from 1.5 to $17.5 \%$ respectively and this variation shows increasing trend towards GZ. The variation in value also indicates the soil formation is greater in $\mathrm{GZ}$ from the carbonate and mica minerals. The value $7.5 \%$ of carbonate shows its significant presence in GZ compared with other sedimentation zones. The sources of these minerals are particularly the lesser Himalayan medium grade metamorphic and sedimentary rocks and higher Himalayan crystalline \& carbonate rocks. However, the sub Himalayan portion is shorter in the Koshi basin because the thickness of sub Himalayan zone is decreasing towards the eastern Nepal Himalaya.

The weathering process that disintegrates the minerals eventually helps in the formation of soil. Therefore, it is easy for soil formation from carbonate and mica group of rocks. The presence of mica and carbonate is comparatively higher in GZ and $\mathrm{YZ}$. The $\mathrm{pH}$ value is also influenced by the sediment composition and weathering products. The carbonates enhance the soil alkalinity against the acidity. The mild acidic nature of the normal soil is naturally balancing from the sediments that is brought by water mostly during the flood. Therefore, the

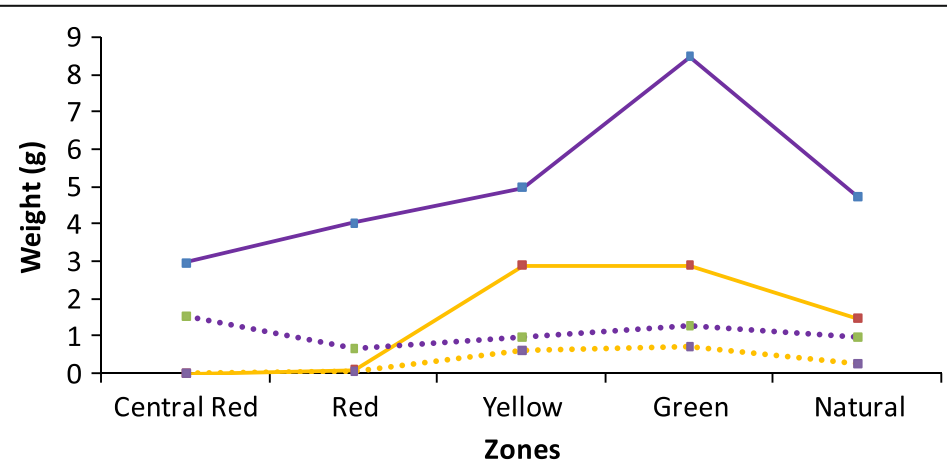

- - Average weight, $g$ (wet) of Wheat $\longrightarrow$ - Average weight, g (wet) of Paddy

...... Average weight, $g$ (dry) of Wheat …. Average weight, g (dry) of Paddy

Fig. 11 Average weight of paddy and wheat in wet and dry conditions 
flood is not always harmful to the soil. It should be accepted as natural process for soil balancing. The mild acidic nature of the normal soil indicates the use of chemical fertilizer in the paddy fields. The higher levels of soil nutrients in the pure forest (Paudel and Sah 2003) in the upstream of the Koshi and the top soil erosion of the catchment surely contributes the nutrients in the downstream. Therefore, the flood can contribute the nutrients to the field to some extent to enhance the soil quality naturally.

Bulk density is lower towards $\mathrm{YZ}$ and GZ compared to NZ and CRZ. Therefore, the loose soil in GZ to YZ is favorable for cultivation. The outcomes support the field practices data and grain size, and moisture analysis to some extent. All these parameters show that the cultivation is favorable in GZ in most of the YZ . Therefore, farmers have been cultivating different cash crops instead of the traditional crops.

The average height is good in GZ compared to the other classified zones. The correlation between height and weight is directly proportional to the relations for the both paddy and wheat. However, the comparative difference is higher for the wheat (Fig. 12). The data also indicated that the wheat does not need as much clay percentage as of paddy. Therefore, the cultivation practices on $\mathrm{YZ}$ is favorable to wheat. However, the paddy does not grow in the sandy soil. Soil texture of "loamy sand" in YZ does not support paddy whereas the GZ soil texture "sandy loam" is favorable for paddy as well as vegetables.

Variation in thickness of sediment layer ranged from 10 to $450 \mathrm{~cm}$ (Fig. 3). The thick sediments are in the new main channel, which is classified as CRZ. The thickness was found to be decreasing towards the downstream or southern part of the affected area. In the breach area, major bends and channel separated area are the most sediment accumulated areas with $100 \mathrm{~cm}$ to $>400 \mathrm{~cm}$. The deposited sediments had controlled a morphology of the new channel. The $>400 \mathrm{~cm}$ thick sediments had forced to bend the river from SW to SE, $150 \mathrm{~cm}$ thick sediments forced to southwards on the side of the embankment are the examples of river morphological control. The deposits act as an obstruction for the flow and force the separation of channel as braided system in most of the flooded area. The thickness is low in Left GZ compared with Right GZ. The inundation depth on upstream or northeastern part of the new channel is low with compare to moving water area or southwestern part of the flooded area.

The sediments thickness profile shows the sedimentation accumulation is high in CRZ and RZ area, whereas the banks of the new channel area has low accumulation of the sediments (Figs. 13 and 3)

The assessment on agriculture practices shows that the average affected years for the cultivation varies from 6 months to 5 years (Fig. 14). The minimum affected years for the GZ to $\mathrm{YZ}$ is 6 months to 2 years, whereas it is longer for the $\mathrm{RZ}$ and $\mathrm{CRZ}$ with an average of 5 years. However, more than 5 years for years taken for the cultivation was also observed in most of CRZ.

The data shows that the flood is not always destructive in all parts of the land. The green zone productivity shows some positive impacts which should be taken into account for the assessment of the post disaster management. The inundation area has high quality of sediment, whereas other areas have been devastated by flood and have negative impacts on the farmland (Kafle et al. 2015).

Based on the observation plots, the different agricultural practices observed after the disaster can be classified into 3 groups.

i Inundation area cultivation

ii Shallow sedimentation area cultivation

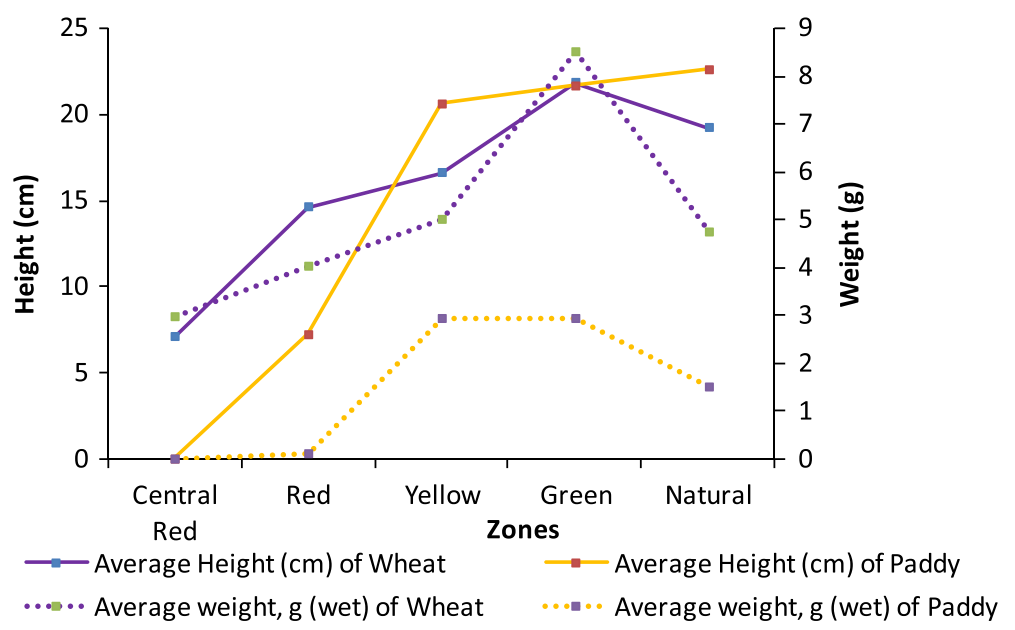

Fig. 12 Average height Vs weight of paddy and wheat 


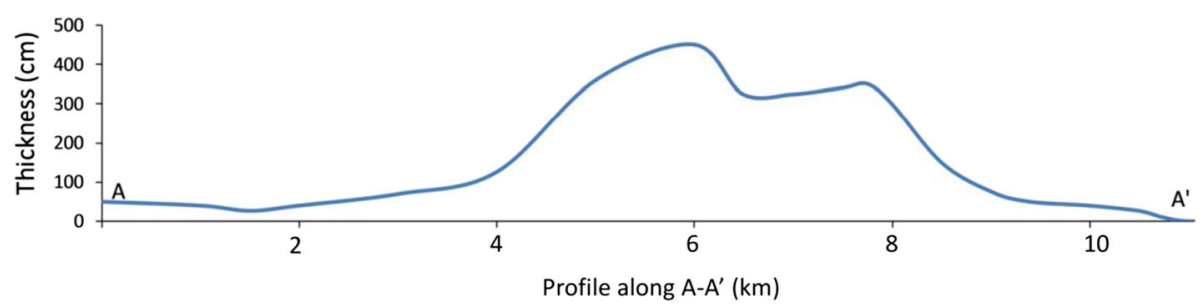

Fig. 13 The sediment profile along A-A' (Fig. 3)

iii Thick sedimentation area cultivation

\section{Inundation area cultivation}

This area can be classified into positive impact area for the productivity. The data also shows that the degree of fineness is greater with new sedimentation, which acts to increase the productivity. $10-20 \mathrm{~cm}$ thick fine sediments have enhanced the productivity of vegetables and grains. In most of this area, farmers are willing to practice vegetable cultivation instead of traditional paddy and wheat. The income has also increased by $200-300 \%$ annually due to the change in the cultivation practices. The data shows that the upstream side (left bank of the new channel) is suitable for vegetable cultivation mostly as the clay percentage in left bank is $4.38 \%$ higher than that of the right bank of the new channel.

This indicates that the right bank green zone does not have much nutrient loaded sediments as in the upstream of same zone (Fig. 15). In the right bank of the new channel, the farmers have started the traditional cultivation of wheat and paddy after 6 months after the flood. The income and productivity is also similar to the situation prior to the flood.

\section{Shallow sedimentation area cultivation}

Most of the shallow sedimentation is occupied by YZ except some of the places of RZ. The crops that are grown in the area are sugercane, watermelon and point guard
(Parbar), where the sedimentation is less than $1.5 \mathrm{~m}$ of thickness. Bombax (Simal) and sugarcane are on practices over the area where thickness is less than $1 \mathrm{~m}$ of sediments, whereas watermelon and point guard are being cultivated where the sediment thickness ranges from 1 to $1.5 \mathrm{~m}$. The clay percentage varies from $<1$ to $5 \%$ in the area. The bombax, sugarcane and point guard are being grown on the higher clay area and watermelon in the areas with lower clay percentage. Bombax (Simal) and watermelon are cultivated by removing of sediments in plantation area or by excavating the pits in the sediments. The income during pre-flood is similar to the post-flood phase with new cultivation method. In case of bombax cultivation, the income has not been confirmed yet because of the immaturity of the plant.

\section{Thick sedimentation area cultivation}

This area is included in parts of the RZ and the CRZ. The thickness of the sediments range from 1 to $4.25 \mathrm{~m}$ in most of the area except some of the places. If the sediment thickness is greater than $2 \mathrm{~m}$, then the land is uncultivable. If the land that has sediment thickness is less than $2 \mathrm{~m}$, then people have removed the sediments by using excavator and tractor to make their land cultivable. The practices can be observed in CZ. In some of the places, the farmers have started the cultivation only after 5 years of the event even in same land for the testing of wheat cultivation. The remaining area where the

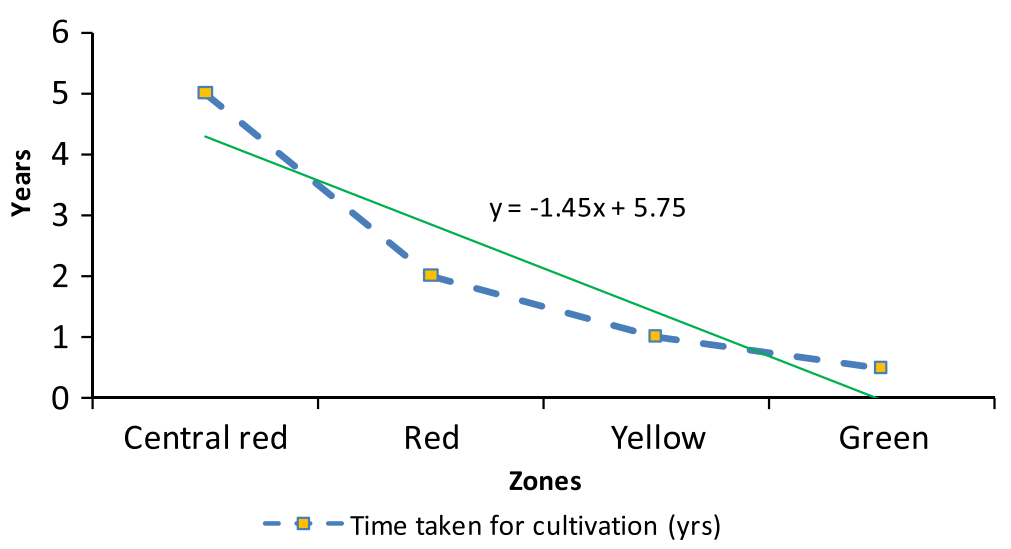

Fig. 14 Time for Starting of cultivation during the post disaster phase 


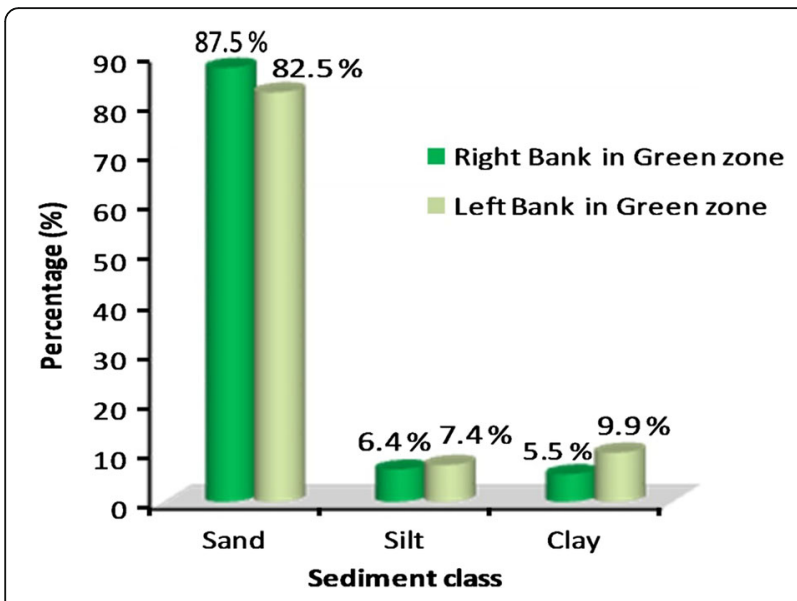

Fig. 15 Average sediment size in GZ

thickness of sediments is greater than $2 \mathrm{~m}$ have remained uncultivated even after 8 years of the event. The grain size analysis also indicates the presence of sand (more than 98\%) in RZ and CRZ, which obviously means cultivation is unsuitable, particularly in CRZ.

The Koshi flood shows that the impact of flood in Nepal is very grave because of the extremely long recovery period of the flood land. Continual barrenness even after 8 years shows the poor management in post disaster phase, however, the adaption practices by affected people are remarkable in the condition of government's minimal efforts.

\section{Conclusion}

The thickness, mineral composition, sediments size are dependent impact variables from the agriculture point of view in post disaster period. In terms of sediment thickness, up to $1.5 \mathrm{~m}$ of thickness is manageable for the cultivation by changing the traditional crops. Wheat cultivation is possible within $1 \mathrm{~m}$ thick sediments whereas the thickness requirements for paddy is less than $30 \mathrm{~cm}$. The crop yield is also $50-75 \%$ greater in green zones (less than $30 \mathrm{~cm}$ of thick sediment) than in the other zones. The change in cultivation practice from traditional crops to cash crops have increased the income by up to $200-300 \%$. Thus, agriculture practices can be adapted with respect to sediments through changing the crops and through new cultivation as well in the aggraded land.

\section{Authors' contributions}

KRK and SNK were responsible for the collecting field data, designed and implemented the methodological framework of the research as well as preparation of the manuscript. SNK supervised the project, RKD gave technical support and conceptual advice, substantial contributions to the conception, design, implementation, analysis of the study. All authors read and approved the final manuscript.

\section{Competing interests}

The authors declare that they have no competing interests.

\section{Author details}

'Department of Environmental Science and Engineering, Kathmandu University, Dhulikhel, Nepal. ${ }^{2}$ Geo-disaster Research Centre, Central Department of Geology, Tribhuvan University, Kirtipur, Nepal.

Received: 12 December 2015 Accepted: 25 January 2017

Published online: 31 January 2017

\section{References}

ADB, Asian Development Bank. 2009. Report and recommendation of the President to the Board of Directors, Proposed Asian Development Fund Grant Nepal. Emergency Flood Damage Rehabilitation Project:2-3.

Agarwal, R.P., and R. Bhoj. 1992. Evolution of Kosi river fan, India: structural implications and geomorphic significance. International Journal of Remote Sensing 13: 1891-1901. doi:10.1080/01431169208904238.

Andermanna, C., A. Cravea, R. Gloaguenb, P. Davya, and S. Bonnetd. 2012. Connecting source and transport: Suspended sediments in the Nepal Himalayas. Earth and Planetary Science Letters 351-352: 158-170. doi:10.1016/.j.epsl.2012.06.059.

AOSA, Association of Official Seed Analysts. 2002. Seed Vigour Testing Handbook, Contribution No. 32 to the Handbook of Seed Testing, NE, USA.

Blair, T.C., and J.G. McPherson. 1994. Alluvial Fans and their Natural Distinction from Rivers Based on Morphology, Hydraulic Processes, Sedimentary Processes, and Facies Assemblages. Journal of Sedimentary Research, Section A: Sedimentary Petrology and Processes 64A: 450-489.

Brown, S., H. Schreier, P.B. Shah, and L.M. Lavkulich. 1999. Modelling of soil nutrient budgets: an assessment of agricultural sustainability in Nepal. Soil Use and Management 15: 101-108.

Desbiez, A., R. Matthews, B. Tripathi, and J. Ellis-Jones. 2004. Perceptions and assessment of soil fertility by farmers in the mid-hills of Nepal. Agriculture, Ecosystems \& Environment 103: 191-206.

Dirkzwager, A.J.E., L. Grievink, P.G. Van der Velden, and C.J. Yzermans. 2006. Risk factors for psychological and physical health problems after a man-made disaster. The British Journal of Psychiatry 189: 144-149. doi:10.1192/bjp.bp.105.017855.

Dixit, A. 2009. Koshi Embankment Breach in Nepal: Need for a Paradigm shift in Responding to Floods. Economic and Political Weekly 44(6):70-78. http://www. jstor.org/stable/40278487.

Galea, S., D. Vlahov, H. Resnick, J. Ahern, E. Susser, J. Gold, et al. 2003. Trends of Probable Post-Traumatic Stress Disorder in New York City after the September 11 Terrorist Attacks. American Journal of Epidemiology 158: 514-524. doi:10.1093/aje/kwg187.

Ghatak, M., A. Kamal, and O.P. Mishra. 2012. Background paper flood risk management in South Asia. In Proceedings of the SAARC Workshop on Flood Risk Management in South Asia.

Gole, C.V., and S.V. Chitale. 1966. Inland delta-building activity of the Kosi River. Journal of the Hydraulics Division American Society of Civil Engineers 92: 111-126.

Guha-Sapir, D., and M.F. Lechat. 1986. Information systems and needs assessment in natural disasters: An approach for better disaster relief management. Disasters 10: 232-237. doi:10.1111/j.1467-7717.1986.tb00594.x.

Hooning, E.M. 2011. Flooding and sediment management on the Koshi alluvial fan, Nepal. Thesis, Dept. of Hydraulic Engineering, TU Delft, Institutional Repository. http://repository.tudelft.nl/islandora/object/uuid:9763a2a4-e1994393-a2ebf7ac7f1dbd78?collection=education. Accessed 12 July 2013.

Hussain, A., Weisaeth, L., and T. Heir. 2009. Nonresponse to a population-based post disaster postal questionnaire study. Journal of Traumatic Stress International Society for Traumatic Stress Studies. doi:10.1002/jts.20431.

ISTA, International Seed Testing Association. 2009. International Rules for Seed Testing., Switzerland, 3-98. New York: Wiley.

Jain, V., and R. Sinha. 2005. Response of active tectonics on the alluvial Baghmati River, Himalayan foreland basin, eastern India. Geomorphology 70: 339-356. doi:10.1016/j.geomorph.2005.02.012

Kafle, K.R., Khanal, S.N., and R.K. Dahal. 2015. "Adaptation on sedimentation" in terms of agricultural practices after August Koshi flood, 2008 in Nepal. Journal of Engineering Geology 1094-1104. Special publication. ISSN 0970-5317.

Karlen, D.L., Mausbach, M.J., Doran, J.W., Cline, R.G., Harris, R.F., and G.E. Schuman. 1995. Soil Quality: A Concept, Definition, and Framework for Evaluation (A Guest Editorial). 61: 4-10. doi:10.2136/sssaj1997.03615995006100010001x.

Khalequzzaman, M.D. 1994. Recent Floods in Bangladesh: Possible Causes and Solutions. Recent Studies in Geophysical Hazards 3: 65-80. doi:10.1007/978-94011-0976-5_4. Print ISBN 978-94-010-4423-3.

Mahato, R.K., and J.K. Shukla. 2013. Geomorphological Landforms of Sapt Kosi River Basin. International Journal of Lakes and Rivers 6: 85-101. ISSN 0973-4570. 
MAIB. 2015. My Agriculture Information Bank. http://www.agriinfo.in/?page= topic\&superid=4\&topicid=271. Accessed 10 August 2015.

Malilay, J., W.D. Flanders, and D. Brogan. 1996. A modified cluster-sampling method for post-disaster rapid assessment of needs. Bulletin of the World Health Organization 74: 399-405.

Mazumder, S.K. 2011. Protection Of Flood Embankments by Spurs with reference to Kosi River, paper presented and published in the proc. of HYDRO-2011 held at SVNIT, Surat, Dec. 29-30. http://mww.profskmazumder.com. Accessed 25 Aug 2014.

Moench, M. 2010. Responding to climate and other change processes in complex contexts: Challenges facing development of adaptive policy frameworks in the Ganga Basin. Technological Forecasting and Social Change 6: 975-986.

MoHA. 2009. Ministry of Home Affairs, Government of Nepal, Nepal Disaster Report. The Hazardscape and vulnerability, 2009, 58. http://www.moha.gov.np. Accessed on 15 July 2015.

Nakayama, K., and P.D. Ulak. 1999. Evolution of fluvial style in the Siwalik Group in the foothills of the Nepal Himalaya. Sedimentary Geology 125: 205-224. doi:10.1016/S0037-0738(99)00012-3.

Nayak, J.N. 1996. Sediment management of the Koshi River basin in Nepal. Erosion and Sediment Yield: Global and Regional Perspectives. Proceeding of the Exeter Symposium, July (1996):236. http://hydrologie.org/redbooks/a236/ iahs_236_0583.pdf. Accessed 25 Aug 2014.

Nepal, S., Flügel, W.A., and Shrestha A.B. 2014. Upstream-downstream linkages of hydrological processes in the Himalayan region. Ecological Processes 3: 19. Open Access. Online ISSN 2192-1709, doi:10.1186/s13717-014-0019-4

Önder, E., Ü. Tural, A. Tamer, K. Cengiz, and E. Sarper. 2006. Prevalence of psychiatric disorders three years after the 1999 earthquake in Turkey: Marmara Earthquake Survey (MES). Social Psychiatry and Psychiatric Epidemiology 41: 868-874.

Paudel, S., and J.P. Sah. 2003. Physiochemical characteristics of soil in tropical sal (Shorea robusta Gaertn.) forests in eastern Nepal. Himalayan Journal of Sciences 1: 107-110. ISSN 1727-5210.

Rahman, M.A. 2011. Study on the changes of coastal zone: Chittagong to Cox s Bazar along the Bay of Bengal. In: Global Summit on Coastal Seas, EMECS 9, 28-31. Baltimore, Maryland, USA. August. http://feppcar.org/179/study-onthe-changes-of-coastal-zone-chittagong-tocox\%E2\%80\%99s-bazar-along-thebay-of-bengal/. Accessed 15 July 2015.

Regmi, B.D., and M.A. Zoebisch. 2004. Soil Fertility Status of Bari and Khet Land in a Small Watershed of Middle Hill Region of Nepal. Nepal Agricultural Research Journal 5: 38.

Richards, K., S. Chandra, and P. Friend. 1993. Avulsive channel systems: characteristics and examples. The Geological Society, London, Special Publications 75: 195-203.

Roorda, J., W.A.H.J. Stiphout, and R.R.R. Huijsman-Rubingh. 2004. Evidence based public health policy and practice: Post-disaster health effects: strategies for investigation and data collection. Experiences from the Enschede firework disaster. Journal of Epidemiology and Community Health 58: 982-987. doi:10.1136/jech.2003.014613.

Schelling, D. 1992. The tectonostratigraphy and structure of the eastern Nepal Himalaya 11: 925-943. doi:10.1029/92TC00213.

Schreier, H., S. Brown, L.M. Lavkulich, and P.B. Shah. 1999. Phosphorus dynamics and soil P-fertility constrains in Nepal. Soil Science 164: 341-350.

Sinha, R. 1998. On the controls of fluvial hazards in the north Bihar plains, eastern India The Geological Society, London, Engineering Geology Special Publications 15: 35-40.

Sinha, R., and S. Kommula. 2010. Avulsion threshold in a large Himalayan river: the case of the Kosi, India and Nepal. In The Smithsonian/NASA Astrophysics Data System, American Geophysical Union fall meeting EP24B-07.

Sinha, R., V. Jain, G.P. Babu, and S. Ghosh. 2005. Geomorphic characterization and diversity of the fluvial systems of the Gangetic Plains. Geomorphology 70: 207-225. doi:10.1016/j.geomorph.2005.02.006

Sinha, R., S.K. Tandon, and M.R. Gibling. 2010. Shallow sub-surface stratigraphy of the Ganga basin, Himalayan foreland: Present status and future perspectives. Quaternary 227: 81-86. doi:10.1016/j.quaint.2010.07.015.

Subramanian, V., and A.L. Ramanathan. 1996. Nature of Sediment Load in the Ganges-Brahmaputra River Systems in India, Sea-Level Rise and Coastal Subsidence, Causes, Consequences, and Strategies, In ed. Milliman J.D., and B.U. Haq, 2:151-168. Netherlands: Springer. ISBN 978-90-481-4672-7

THT, The Himalaya Times. 2011. 700 hectares hit by Koshi flood still uncultivable.. 12 Sep.

Tiwari, K.R., B.K. Sitaula, T. Børresen, and R.M. Bajracharya. 2006. An assessment of soil quality in Pokhare Khola watershed of the Middle Mountains in Nepal. Journal of Food, Agriculture \& Environment 4: 276-283.

Walling, D.E. 1988. Erosion and sediment yield research-Some recent perspectives. Journal of Hydrology 100: 113-114. doi:10.1016/0022-1694(88)90183-7.

\section{Submit your manuscript to a SpringerOpen ${ }^{\circ}$ journal and benefit from:}

- Convenient online submission

- Rigorous peer review

- Immediate publication on acceptance

- Open access: articles freely available online

- High visibility within the field

- Retaining the copyright to your article

Submit your next manuscript at $>$ springeropen.com 